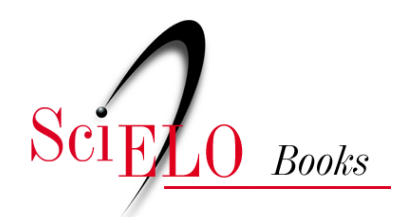

\title{
28 Tribo Eupatorieae Cass.
}

\author{
Jimi Naoki Nakajima \\ Silvana da Costa Ferreira \\ Ana Claudia Fernandes \\ Vanessa Lopes Rivera \\ Eric Koiti Okiyama Hattori \\ Aline Silva Quaresma \\ Mara Rejane Ritter \\ Mariana Andrea Grossi
}

NAKAJIMA, J.N., FERREIRA, S.C., FERNANDES, A.C., RIVERA, V.L., HATTORI, E.K.O., QUARESMA, A.S., RITTER, M.R., and GROSSI, M.A. Tribo Eupatorieae Cass. In: ROQUE, N. TELES, A.M., and NAKAJIMA, J.N., comp. A família Asteraceae no Brasil: classificação e diversidade [online]. Salvador: EDUFBA, 2017, pp. 209-230. ISBN: 978-85-232-1999-4. https://doi.org/10.7476/9788523219994.0030.

All the contents of this work, except where otherwise noted, is licensed under a Creative Commons Attribution 4.0 International license.

Todo o conteúdo deste trabalho, exceto quando houver ressalva, é publicado sob a licença Creative Commons Atribição 4.0. 


\title{
TRIBO EUPATORIEAE CASS.
}

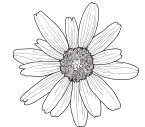 \\ Jimi Naoki Nakajima \\ Silvana da Costa Ferreira \\ Ana Claudia Fernandes \\ Vanessa Lopes Rivera \\ Eric Koiti Okiyama Hattori \\ Aline Silva Quaresma \\ Mara Rejane Ritter \\ Mariana Andrea Grossi
}

A tribo Eupatorieae foi uma das primeiras tribos a serem reconhecidas na classificação de Asteraceae (BREMER, 1994), sendo aceita atualmente como monofilética e pertencente ao clado da Aliança Heliantheae (HIND; ROBINSON, 2007; PANERO; CROZIER, 2016; PANERO; FUNK, 2008). As características mais marcantes dessa tribo são as suas folhas geralmente opostas, capítulos discoides, ramos do estilete com apêndices estéreis alongados, obtusos e coloridos e cipselas com fitomelanina (ROBINSON; SCHILLING; PANERO, 2009).

A tribo foi intensivamente estudada entre as décadas de 1970 e 1990, com base no estudo de microcaracterísticas florais, o que resultou em muitas mudanças taxonômicas (KING; ROBINSON, 1987). Dentre elas, a segregação e reconhecimento de uma centena de gêneros a partir de Eupatorium L. (BREMER, 1994), que ficou circunscrito ao Hemisfério Norte, concentrado na América do Norte, com algumas espécies ocorrendo naturalmente na Ásia e Europa (KING; ROBINSON, 1987).

Entretanto, muitos estudos taxonômicos ou tratamentos sistemáticos realizados com a tribo Eupatorieae no Brasil - por exemplo Matzenbacher (1979), Cabrera e Klein (1989) e Barroso (1991) - não utilizaram essa nova 
classificação e continuaram a adotar o conceito tradicional de Eupatorium L. (sensu BAKER, 1876), dificultando a compreensão dos táxons dessa tribo.

Recentemente, um estudo filogenético baseado em marcadores moleculares foi realizado (RIVERA et al., 2016) com enfoque nas Eupatorieae brasileiras. Os resultados revelaram muitos gêneros e subtribos polifiléticos, indicando que a classificação de Eupatorieae poderá passar por uma nova mudança.

A tribo apresenta diversas espécies na América do Norte e poucas espécies pantropicais ou no Velho Mundo, sendo essencialmente neotropical e concentrada no México e nas Américas Central e do Sul (ROBINSON; SCHILLING; PANERO, 2009). Eupatorieae conta com cerca de 182 gêneros, arranjados em 17 subtribos e cerca de 2.200 espécies (HIND; ROBINSON, 2007; ROBINSON; SCHILLING; PANERO, 2009).

\section{Descrição}

Ervas, arbustos ou lianas, raramente pequenas árvores, ervas aquáticas ou epífitas. Folhas geralmente opostas, frequentemente pecioladas, inteiras, às vezes lobado-pinatissectas ou dissectas, geralmente trinervadas. Capitulescências geralmente corimboso-paniculiformes, às vezes tirsoideo-paniculiformes, espiciformes ou glomeruliformes, raramente capítulos isolados. Capítulos homógamos, discoides, raramente unifloros; invólucro subimbricado a imbricado, brácteas involucrais 1-2-seriadas a multisseriadas, geralmente persistentes, raramente parcial ou totalmente caducas; receptáculo epaleáceo, raramente paleáceo, glabro. Flores bissexuais, corola tubulosa, 5-lobada, raramente 4-lobada, actinomorfa, às vezes flores marginais com corola zigomorfa, alvas, róseas, púrpura ou violeta, nunca amarelas; anteras com apêndice oval-lanceolado a oblongo, plano, raramente truncado, emarginado, ou ausente, base obtusa, ecaudada, às vezes curtamente calcarada, colar cilíndrico, às vezes base alargada; estilete com ramos longo exsertos, filiforme-lineares a oblanceolado-clavados, apêndices estéreis obtusos, mamilosos a longo papilosos, geralmente coloridos, 2 áreas estigmáticas distintas, às vezes glanduloso entre as áreas estigmáticas, estilopódio glabro ou pubescente. Cipselas uniformes, geralmente oblon- 
gas, prismáticas, raramente achatadas, geralmente enegrecidas, 5-costadas, mais raramente 7-10-costadas, glabras ou pubescentes, tricomas duplos; pápus cerdoso, simples, cerdas escábrido-barbeladas, raramente plumoso, paleáceo-aristado, coroniforme ou ausente.

No Brasil, essa tribo é a mais rica em número de gêneros e espécies (88 gêneros e 607 espécies). Muitos gêneros e espécies são endêmicos (40 gêneros e 440 espécies), ocorrendo principalmente nas regiões Sul, Sudeste e Centro-Oeste (BFG, 2015). Representantes de Eupatorieae estão destacados nas Figuras 24 a 27.

\section{Chave de identificação para os gêneros de Eupatorieae no Brasil}

1. Brácteas involucrais fundidas na base, receptáculo epaleáceo, sem tecido esclerificado entre as cicatrizes da cipsela 2

1'. Brácteas involucrais livres desde a base, receptáculo paleáceo ou epaleáceo e com tecido esclerificado entre as cicatrizes da cipsela ............. 4

2. Cipsela com carpopódio simétrico; pápus ausente Gymnocoronis 2'. Cipsela com carpopódio assimétrico; pápus constituído de pequenos bastões com tricomas glandulares no ápice (Figura 22B) 3

3. Cipsela levemente curvada (Figura 22B); pápus geralmente com 3 bastões, raramente 5 Adenostemma

3'. Cipsela não curvada, pápus com 5 bastões. Sciadocephala

4. Capítulos com número igual de flores e brácteas involucrais 5

4'. Capítulos com número diferente de flores e brácteas involucrais. 6

5. Flores e brácteas involucrais em número de 4, subtendidos por 1 bráctea subinvolucral; pápus sempre cerdoso. Mikania 5'. Flores e brácteas involucrais em número de 5, sem bráctea subinvolucral; pápus cerdoso (Figuras 23G-H), paleáceo-aristado, aristado ou coroniforme Stevia 
6. Todas as brácteas involucrais caducas, deixando o receptáculo exposto...

6'. Brácteas involucrais externas persistentes; as internas, às vezes, caducas

7. Receptáculo cônico a colunar; cipselas comprimidas (achatadas), com 2-4 costas marginais, ciliadas, carpopódio assimétrico (lateral na base da cipsela) 8

7'. Receptáculo plano; cipselas prismáticas, geralmente com 5 costas; carpopódio simétrico ou obsoleto 10

8. Pápus de cerdas curtas, desiguais Eupatoriopsis

8’. Pápus de cerdas longas, iguais 9

9. Cipsela com 2 costas marginais densamente setulíferas (Figura 22J), pápus com 2-8 cerdas, rígidas, com ou sem cerdas pequenas adicionais

Eitenia

9'. Cipsela com 3-4 costas esparsamente setulífera; pápus 20-40 cerdas capilares Praxelis

10. Flores periféricas com lobos da corola patentes, zigomorfos; ramos do estilete com base alargada; pápus com 5 cerdas Praxeliopsis 10'. Flores periféricas com lobos da corola eretos, actinomorfos; base do estilete cilíndrica; pápus com muitas cerdas longas ou cerdas curtas, desiguais

11. Plantas recobertas por glândulas estipitadas; folhas lobadas a profundamente dissectas; carpopódio pouco diferenciado; pápus com cerdas curtas, desiguais

Lomatozona

11'. Plantas não recobertas por glândulas estipitadas; folhas não lobadas ou dissectas; carpopódio distinto, curtamente cilíndrico; pápus com cerdas longas iguais ou subiguais Chromolaena

12. Receptáculo cônico a colunar, paleáceo (todas as flores subentendidas por páleas ou brácteas involucrais mais internas) Isocarpha 12'. Receptáculo plano, convexo ou cônico, epaleáceo ou paleáceo (páleas dispersas e não subentendendo as flores) 13 
13. Estilete pubescente abaixo da bifurcação

Stylotrichium

13'. Estilete glabro abaixo da bifurcação (Figura 22K) ou com indumento apenas na base (Figuras 22F,I)

14. Corola com lobos internamente papilosos, mamilosos, ou células com paredes sinuosas alongadas, projetando-se como papilas em ambas as superfícies ................................................................................................ 15

14'. Corola com lobos internamente lisos..................................................... 51

15. Lâmina foliar com venação subparalela; brácteas involucrais e páleas do receptáculo com apêndices apicais cartáceos e sinuosos (Figura 23E).

Scherya

15'. Lâmina foliar com venação diferente; brácteas involucrais sem apêndices apicais; páleas do receptáculo sem ápice cartáceo, ou receptáculo epaleáceo.

16. Pápus ausente, coroniforme, paleáceo-aristado, paleáceo, raramente com mais de 5 elementos ......................................................................... 17

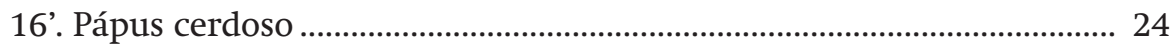

17. Receptáculo paleáceo............................................................................... 18

17'. Receptáculo epaleáceo ......................................................................... 20

18. Brácteas involucrais 30-40; receptáculo cônico............................ Ageratum 18'. Brácteas involucrais 5-25; receptáculo plano ou levemente convexo......

19. Ervas; páleas com ápice densamente fimbriado; base da corola fundida com o ápice da cipsela Teixeiranthus 19'. Arbustos; páleas com ápice inteiro; corola não fundida com a cipsela .. Acritopappus

20. Receptáculo cônico; pápus com 5 paléas aristadas. Ageratum 20'. Receptáculo plano ou convexo; pápus diferente. 21

21. Pápus de 5 escamas curtas Radlkoferotoma

21'. Pápus ausente 22

22. Corola externamente glabra Piqueriella 22'. Corola externamente pilosa 
23. Lâmina foliar repando-denteada a pinatífida; corola infundibuliforme, base glanduloso-estipitada (Figura 22L). Gardnerina 23'. Lâmina foliar inteira ou lobada; corola com tubo constrito, densamente recoberto por tricomas tectores Cavalcantia

24. Ramos do estilete longo-papilosos (Figura 22K); células da superfície mais interna dos lobos da corola com paredes sinuosas alongadas, projetando-se como papilas; colar da antera inconspícuo Fleischmannia 24'. Ramos do estilete papilosos ou mamilosos; lobos da corola com células isodiamétricas; colar da antera geralmente conspícuo e expandido 25

25. Plantas com folhas crassas 26 25’. Plantas com folhas herbáceas, cartáceas ou coriáceas, nunca crassas ...

26. Folhas dispostas em roseta basal; capítulos dispostos no ápice de um escapo floral; receptáculo cônico com cicatrizes pronunciadas

Bishopiella

26'. Folhas dispostas ao longo do caule; capítulos não dispostos em escapo floral; receptáculo plano a levemente convexo com cicatrizes não pronunciadas 27

27. Plantas viscosas, geralmente longo-pecioladas (maior que $1,5 \mathrm{~cm}$ compr.); capítulos pêndulos após a senescência; corola com ductos de resina pareados com as nervuras do tubo; pápus com cerdas curtas (Figura 23A) Morithammus

27'. Plantas não viscosas, geralmente curto-pecioladas (até 1,5 cm compr.); capítulos eretos após a senescência; corola sem ductos de resina; pápus com cerdas longas. 28

28. Lâmina foliar plana, inteira, glabra; brácteas involucrais oblongas ou elípticas; pápus com cerdas creme Litothamnus 28'. Lâmina foliar conduplicada, denteada a denticulada, tomentosa; brácteas involucrais linear-lanceoladas ou oblanceoladas; pápus com cerdas púrpura ou alvas com ápice púrpura Lapidia 
29. Pápus plumoso (Figura 23K) ou ausente; se ausente, corola apresentando densa pubescência nos lobos ........................................................................... 30 29'. Pápus cerdoso, subplumoso ou ausente; se ausente, corola não apresentando densa pubescência nos lobos

30. Caule estriado; corola densamente pubescente nos lobos (Figura 23J); apêndice do conectivo da antera obtuso a levemente retuso.... Trichogonia 30'. Caule liso, raramente estriado; corola com tricomas glandulares nos lobos; apêndice do conectivo da antera bilobado Trichogoniopsis

31. Filotaxia alterno-espiralada, folhas congestas, não diminuindo de tamanho em direção ao ápice da planta 32 31'. Filotaxia oposta ou alterna, folhas laxas, geralmente diminuindo de tamanho em direção ao ápice da planta 39

32. Arbustos a árvores $2-5 \mathrm{~cm}$ alt.; ápice dos ramos e face abaxial da lâmina foliar velutino-ferrugíneo; lâmina foliar largamente ovada $(7-17$ x 2-13 cm), longo-pecioladas (2-6 cm compr.); flores alvo-róseas, aromáticas...... Kaunia 32'. Sem o conjunto das características acima 33

33. Receptáculo paleáceo 34

33'. Receptáculo epaleáceo 36

34. Lâmina foliar linear; capítulos solitários; páleas somente nas flores externas Arrojadocharis 34'. Lâmina foliar lanceolada ou elíptica; capitulescência corimbiforme, raro capítulos solitários; páleas distribuídas em todo o receptáculo 35

35. Invólucro em 2 séries, brácteas involucrais decíduas; ramos do estilete cilíndricos (Figura 22G); pápus ausente ou inconspícuo (0,1 mm compr.) ... Catolesia

35'. Invólucro em 3-5 séries, brácteas involucrais persistentes; ramos de estilete clavados (Figura 22C); pápus presente, raramente ausente

Agrianthus

36. Plantas viscosas; receptáculo plano 37

36'. Plantas não viscosas; receptáculo cônico ou convexo 38 
37. Plantas pubescentes (tricomas glandulares estipitados e eglandulares); cipselas aladas, com presença de calos ao longo das costas (Figura 23F), pápus com cerca de 5 cerdas ou ausente. Semiria

37’. Plantas glabras; cipselas não aladas, calos ausentes, pápus com cerca de 30 cerdas Bahianthus

38. Caule e face abaxial da lâmina foliar cobertos por indumento lanoso; receptáculo piloso (Figura 22P) Lasiolaena 38'. Caule e lâmina foliar glabros ou glabrescentes; receptáculo glabro

Agrianthus

39. Cipselas com a base estipitada (Figura $22 \mathrm{H}$ ) 40

39'. Cipselas com base cilíndrica (Figuras 22D-E, 23A-B)

40. Ervas; anteras com apêndice truncado; base do estilete glabra; pápus subplumoso Platypodanthera 40'. Subarbustos; anteras com apêndice agudo ou obtuso; base do estilete pilosa (Figura 22F); pápus cerdoso 41

41. Receptáculo cônico, com projeções que circundam a inserção da cipsela; corola com lobos tão longos quanto largos; cipsela com as costas creme e fortemente setulíferas

Campuloclinium 41'. Receptáculo plano e foveolado; corola com lobos cerca de 3 vezes mais longos que largos; cipselas e costas concolores, algumas vezes levemente barbeladas Macropodina

42. Estilete com base buliforme, pilosa (Figura 22I) 43

42'. Estilete com base cilíndrica, glabra 44

43. Brácteas involucrais dispostas em 2 séries subiguais em comprimento, receptáculo convexo; anteras com apêndice do conectivo bilobado a emarginado. Diacranthera 43'. Brácteas involucrais dispostas em 3-4 séries desiguais em comprimento, receptáculo cônico; anteras com apêndice do conectivo inteiro, agudo ou obtuso Dasycondylus

44. Receptáculo plano ou levemente convexo 45

44'. Receptáculo subgloboso, cônico ou convexo 48 
45. Ervas com capitulescência subescaposa; brácteas involucrais mais internas com ápice arredondado ou truncado, completamente coberto por denso indumento alvo-tomentoso Gyptis 45'. Subarbustos com capitulescências terminais; brácteas involucrais com ápice agudo não recoberto por indumento alvo-tomentoso. 46

46. Folhas sésseis ou subsésseis; cipselas 7-10-costadas Vittetia 46'. Folhas peciolada; cipselas 5-costadas 47

47. Plantas de restinga; lâmina foliar pinada, brilhante; capítulos 12-14 flores; brácteas involucrais subiguais; cipsela glabra ou com 1-2 cerdas no ápice Prolobus 47'. Plantas de cerrado e caatinga; lâmina foliar trinervada, opaca; capítulos 5-10 flores; brácteas involucrais desiguais; cipsela setulífera e tricomas glandulares

Bejaranoa

48. Receptáculo piloso; pápus com cerdas de ápice obtuso, inflado ......... 49

48’. Receptáculo glabro; pápus com cerdas de ápice agudo ......................... 50

49. Lâmina foliar com base foliar cordada; capitulescência densa, capítulos 100-150 flores; brácteas involucrais com ápice caudado, tomentoso; carpopódio distinto.............................................................................. Urolepis 49'. Lâmina foliar com base truncada; capitulescência laxa, capítulos 5080 flores; brácteas involucrais com ápice agudo, pubescente; carpopódio inconspícuo

Gyptidium

50. Cipselas com tricomas glandulares sésseis (Figura 22E); carpopódio decorrente nas costas da cipsela Barrosoa 50'. Cipselas densamente pubescentes, tricomas glandulares ausentes; carpopódio anuliforme e não decorrente Conocliniopsis

51. Corola com limbo constrito abaixo dos lobos; ramos do estilete longo clavados, espessados; cipselas 5-10 costas 52 51'. Corola com limbo cilíndrico ou infundibuliforme abaixo dos lobos (sem constrição); ramos do estilete não espessados ou espessados somente no ápice; se longo clavado, então achatado; cipselas 4-5 costas 58 
52. Pápus ausente ou de cerdas facilmente caducas 53

52'. Pápus presente e persistente na maturidade do fruto

53. Folhas dispostas ao longo dos ramos; capítulos subtendidos por brácteas da altura dos capítulos, cobertas de tricomas glandulares; flores com corola rósea, externamente pubescente e com tricomas glandulares estipitados ... Planaltoa 53'. Folhas dispostas no ápice dos ramos; capítulos não subtendidos por brácteas da altura dos capítulos; flores com corola branca, externamente glabra

Leptoclinium

54. Pápus de cerdas de tamanhos desiguais ................................................. 55

54'. Pápus de cerdas de mesmo tamanho........................................................ 56

55. Folhas sempre opostas; lâmina foliar ovada; capítulo com 6-8 flores; cipsela 5-costada; pápus com cerdas livres Dissothrix 55'. Folhas opostas ou alternas na mesma planta; lâmina foliar oblanceolada; capítulo com 4 flores; cipsela 7-costada; pápus com cerdas fortemente unidas em um calo no ápice da cipsela.....

Goyazianthus

56. Folhas alternas, densamente espiraladas, lâmina foliar linear.

Pseudobrickellia

56'. Folhas opostas, lâmina foliar ovada

57. Arbustos decumbentes; cipselas 5-costadas Austrobrickellia 57'. Ervas; cipselas 8-10-costadas. Brickellia

58. Base do estilete cilíndrica e glabra; brácteas involucrais internas geralmente caducas 59

58'. Base do estilete cilíndrica pubescente ou alargada glabra ou pubescente; brácteas involucrais internas persistentes 80

59. Capítulos sempre com 5 flores; ramos do estilete com ápice papiloso; pápus com cerdas com ápice espessado 60 59'. Capítulos com 1-300 flores; ramos do estilete geralmente lisos, pelo menos no ápice; pápus com cerdas com ápice nunca espessado 65

60. Capítulos dispostos em panículas de racemos laxas 61 60'. Capítulos dispostos em corimbos terminais densos 62 
61. Lâmina foliar inteira; corola com tubo glanduloso (Figura 23D); ramos do estilete densamente papilosos Raulinoreitzia 61'. Lâmina foliar pinatilobada a pinatissecta; corola com tubo glabro; ramos do estilete aciculado-papilosos (Figura 22A). Acanthostyles

62. Folhas vernicosas, ramos sem tricomas tectores Symphyopappus 62'. Folhas não vernicosas, ramos com tricomas tectores 63

63. Invólucro com 1 série de brácteas externas subuladas maiores que as demais brácteas e frequentemente avermelhadas Grazielia 63'. Invólucro com a série de brácteas externas menores que as mais internas 64

64. Folhas densamente espiraladas; base das cipselas sem carpopódio distinto Disynaphia 64'. Folhas geralmente opostas; base das cipselas com carpopódio distinto Campovassouria

65. Receptáculo glabro; colar da antera até 5 vezes mais comprido do que largo 66

65'. Receptáculo geralmente pubescente; colar da antera 5-10 vezes mais comprido que largo. 78

66. Trepadeiras ou plantas escandentes 67

66'. Pequenas árvores, arbustos, subarbustos ou ervas 68

67. Flores 3-5, corola com lobos oblongos, 2-4 vezes tão longos quanto largos (Figura 23I) e massa densa de tricomas tectores internamente na corola, logo abaixo dos lobos; cipsela com pubescência densa e curta

Steyermarkina

67'. Flores 8-10, corola com lobos oblongo-triangulares, mais de 2 vezes mais longos do que largos, glabros; cipsela esparsamente setulífera

Santosia

68. Invólucro com brácteas subimbricadas (as brácteas são progressivamente maiores em séries sobrepostas) 69 68'. Invólucro com brácteas eximbricadas (as brácteas têm comprimentos semelhantes) 75 
69. Folhas com laticíferos, ou seja, com bolsas secretoras translúcidas nas aréolas das folhas, entre as vênulas; brácteas involucrais internas facilmente decíduas Critonia 69'. Folhas sem laticíferos; todas as brácteas involucrais persistentes ..... 70

70. Ramos e folhas vilosas, com tricomas de base distintamente alargada; receptáculo densamente hirsuto Imeria 70'. Ramos e folhas com tricomas de outros tipos; receptáculo glabro ou paleáceo 71

71. Flores com corola internamente pubescente; apêndice das anteras retuso (Figura 23C) ou bilobado Neocabreria 71'. Flores sem essa combinação de caracteres. 72

72. Corola glabra; carpopódio distintamente cilíndrico; pápus formado por 40-50 cerdas fortemente escabras ou barbeladas na base, que se tornam progressivamente lisas em direção ao ápice Austrocritonia 72'. Corola pilosa ou glandulosa; carpopódio obsoleto ou anuliforme; pápus com cerdas iguais em toda a sua extensão 73

73. Receptáculo com poucas páleas Idiothamnus 73'. Receptáculo glabro 74

74. Invólucro campanulado com 20 brácteas, desiguais, apêndice da antera levemente mais longo que largo, ramos do estilete estreitos, lineares, e levemente a distintamente mamilosos Malmeanthus 74'. Invólucro com 7-16 brácteas subiguais, apêndices mais largos que longos, por vezes muito curtos, ramos do estilete bem largos e se tornando lisos no ápice, não glandulares (Figura 22O) Koanophyllon

75. Capitulescência em panícula tirsoide composta por capítulos sésseis organizados em aglomerados esféricos ou globosos Sphaereupatorium 75'. Capitulescência sem capítulos organizados em aglomerados globosos.. 76 
76. Corola com tubo estreito e limbo estreito campanulado; invólucro eximbricado; apêndice das anteras conspícuo, mais longo do que largo .......

Chacoa

76'. Corola infundibuliforme ou com tubo constrito; invólucro subimbricado; apêndice das anteras encurtado ou vestigial 77

77. Invólucro com 4-8 brácteas involucrais em 1-2 séries desiguais, eretas; ramos do estilete com ápice alargado. Ophryosporus 77’. Invólucro com 7-16 brácteas involucrais em 2-4 séries subiguais, espaçando com a maturidade; ramos do estilete com ápice cilíndrico, obtuso Koanophyllon

78. Receptáculo marcadamente convexo até hemisférico; ramos do estilete filiformes (Figura 22N); carpopódio alongado (Figura 22M) Hebeclinium 78'. Receptáculo ligeiramente convexo; ramos do estilete lineares a ligeiramente clavados; carpopódio anuliforme 79

79. Carpopódio simétrico; receptáculo pouco a densamente pubescente, raramente glabro. Bartlettina 79’. Carpopódio fortemente assimétrico; receptáculo glabro Guayania 80. Base do estilete cilíndrica com tricomas; pápus com cerdas com células apicais geralmente arredondadas 81 80'. Base do estilete alargada com ou sem tricomas; pápus com células apicais agudas 83

81. Cipselas glabras ou somente com tricomas glandulares (Figura 22D) .... Austroeupatorium 81'. Cipselas com numerosos tricomas tectores geminados, às vezes com tricomas glandulares escassos 82

82. Capitulescência corimbiforme; brácteas involucrais 12-15; capítulos 1025 flores; estilete com ramos distintamente papilosos; cipsela levemente estipitada Hatschbachiella 82'. Capitulescência piramidal ou tirsoide; brácteas involucrais 5-12(19); capítulos 3-10(25) flores; estilete com ramos papilosos na base ou lisos quando alargados; cipsela cilíndrica Stomatanthes 
83. Ervas diminutas (até $10 \mathrm{~cm}$ alt.); capítulos com até 10 flores, anteras sem apêndice apical Parapiqueria

83'. Subarbustos eretos ou escandentes; capítulos com mais de 20 flores, anteras com apêndice apical........................................................................ 84

84. Pápus com apenas 1 cerda ou ausente (Figura 23B) ............................ 85

84'. Pápus com 5 a muitas cerdas............................................................... 86

85. Folhas opostas a subopostas, lâmina foliar inteira; brácteas involucrais 20-30; pápus decíduo Alomiella 85'. Folhas alternas, basais opostas, lâmina foliar tripinatífida; brácteas involucrais 15; pápus persistente Monogereion

86. Ramos do estilete densamente papilosos; base do estilete alargada e glabra 87

86'. Ramos do estilete lisos a mamilosos; base do estilete alargada e frequentemente com tricomas. 88

87. Brácteas involucrais 15-35; capítulos 5-40 flores; lobos da corola com glândulas na superfície externa; ramos do estilete filiformes; pápus 20-40 cerdas Ayapana

87’. Brácteas involucrais cerca de 50; capítulos 60-80 flores; lobos da corola com tricomas na superfície externa; ramos do estilete clavados; pápus 5-10 cerdas Gymnocondylus

88. Folhas densamente lanuginosas; brácteas involucrais 30-50; carpopódio cilíndrico Ayapanopsis 88'. Folhas hirsutas ou glandulares, mas nunca densamente lanuginosas; brácteas involucrais 15-30; carpopódio contorcido. Heterocondylus

\section{Literatura recomendada}

AMORIM, V. O.; ROQUE, N. Stylotrichium hortensiae (AsteraceaeEupatorieae): A new species from Chapada Diamantina, Bahia, Brazil. Phytotaxa, Auckland, v. 308, n. 2, p. 283-288, 2017. 
BAKER, J. G. Compositae - Vernoniaceae \& Eupatoriaceae. In: MARTIUS, C. P. von; EICHLER, A. W. (Ed.). Flora Brasiliensis. Muchen: [s.n.], 1876. v. 6, n. 2, p. 1-398.

BARROSO, G. M. Sistemática de Angiospermas do Brasil. Viçosa: UFV, 1991. v. 3. BRAZIL FLORA GROUP- BFG. Growing knowledge: an overview of seed plant diversity in Brazil. Rodriguésia, Rio de Janeiro, v. 66, n. 4, p. 10851113, 2015.

BREMER, K. Asteraceae: cladistics and classification. Portland: Timber Press, 1994.

CABRERA, A. L.; KLEIN, R. M. Compostas. 4: Tribo Eupatorieae. Itajaí: Herbário Barbosa Rodrigues, 1989. (Flora Ilustrada Catarinense).

HIND, D. J. N.; ROBINSON, H. Eupatorieae. In: KUBITZKI, K. (Ed.). The Families and Genera of Vascular Plant: v. VIII: Flowering Plants Eudicots: Asterales. Berlin: Springer-Verlag, 2007. p. 510-572.

KING, R. M.; ROBINSON, H. The genera of the Eupatorieae (Asteraceae). Monographs in Systematic Botany from the Missouri Botanical Garden, v. 22, p. 1-581, 1987.

MATZENBACHER, N. I. Estudo taxonômico de gênero Eupatorium L. (Compositae) no Rio Grande do Sul - Brasil. 1979. 310 f. Dissertação (Mestrado em Botânica) - Universidade Federal do Rio Grande do Sul, Porto Alegre, 1979.

PANERO, J. L.; CROZIER, B. S. Macroevolutionary dynamics in the early diversification of Asteraceae. Molecular Phylogenetics and Evolution, Orlando, v. 99, p. 116-132, 2016.

RIVERA, V. L et al. Origins and recent radiation of Brazilian Eupatorieae (Asteraceae) in the eastern Cerrado and Atlantic Forest. Molecular Phylogenetics and Evolution, Orlando, v. 97, p. 90-100, 2016.

ROBINSON, H.; SCHILLING, E.; PANERO, J. L. Eupatorieae. In: FUNK, V. et al. (Ed.). Systematics, Evolution and Biogeography of Compositae. Vienna: IAPT, 2009. cap. 43. p. 731-744. 


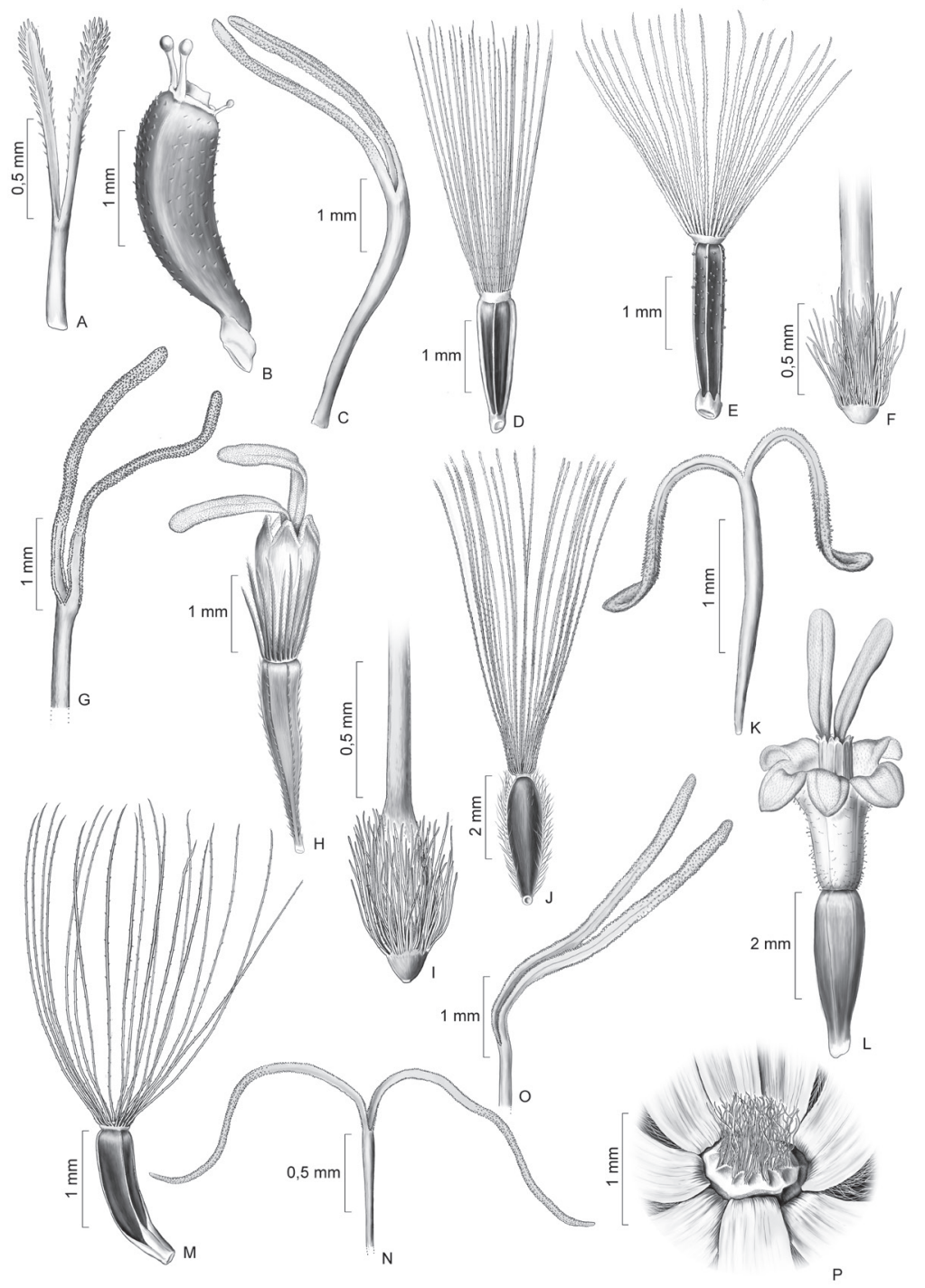

Figura 22. Eupatorieae. A. Ramos de estilete de Acanthostyles buniifolius (Hook. \& Arn.) R.M. King \& H. Rob.; B. Cipsela de Adenostemma brasilianum (Pers.) Cass.; C. Ramos do estilete clavados de Agrianthus empetrifolius Mart. ex DC.; D. Cipsela e pápus de Austroeupatorium silphiifolium (Mart.) R.M. King \& H. Rob.; E. Cipsela e pápus de Barrosoa organensis (Gardner) R.M. King \& H. Rob.; F. Base do estilete pilosa de Campuloclinium hirsutum Gardner; G. Ramos do estilete cilíndrico de Catolesia mentiens D.J.N. Hind; H. Flor de Platypodanthera melissifolia (DC.) M. King \& H. Rob.; I. Estilopódio buliforme e piloso de Diacranthera ulei R.M. King \& H. Rob.; J. Cipsela e pápus de Eitenia polysecta R.M. King \& H. Rob.; K. Ramos do estilete de Fleischmannia remotiflora (DC.) R.M. King. \& H. Rob.; L. Tubo da corola com tricomas glandulares em Gardnerina angustata (Gardner) R.M. King \& H. Rob. M-N. Hebeclinium macrophyllum (L.) DC.: M. Cipsela e pápus com carpopódio decorrente; N. Ramos do estilete filiformes; O. Ramos do estilete de Koanophyllon adamantium (Gardner) R.M. King \& H. Rob.; P. Receptáculo piloso de Lasiolaena blanchetii (Sch. Bip. ex Baker) R.M. King \& H. Rob. 


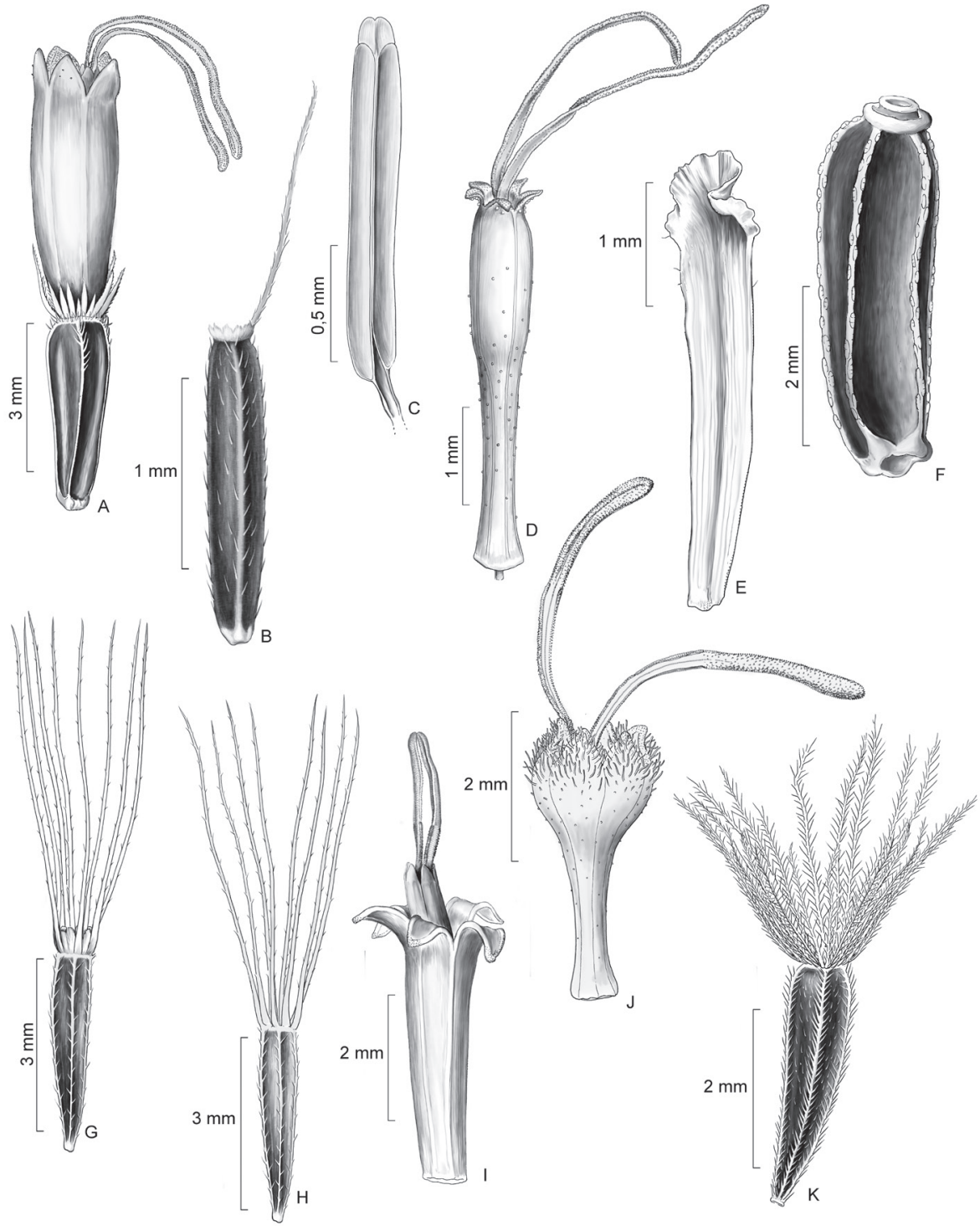

Figura 23. Eupatorieae. A. Flor de Morithamnus crassus R.M. King \& H. Rob.; B. Cipsela e pápus de Monogereion carajensis G.M. Barroso \& R.M. King; C. Apêndice do conectivo retuso de Neocabreria serrulata (DC.) R.M. King. \& H. Rob.; D. Corola e ramos do estilete de Raulinoreitzia crenulata (Spreng.) R.M. King \& H. Rob.; E. Pálea com ápice cartáceo sinuoso de Scherya bahiensis R.M. King \& H. Rob.; F. Cipsela de Semiria sp.; G-H. Cipsela e pápus de Stevia grazielae A.S. Quaresma \& J.N. Nakaj.; I. Corola, ápice dos estames e ramos do estilete de Steyermarkina dusenii (Malme) R.M. King \& H. Rob.; J-K. Trichogonia campestris Gardner: J. Corola com lacínias pilosas e ramos do estilete; K. Cipsela e pápus plumoso. 




Figura 24. Eupatorieae. A. Acanthostyles buniifolius (Hook. ex Arn.) R.M. King \& H. Rob.; B. Acritopappus micropappus (Baker) R.M. King \& H. Rob.; C. Ageratum fastigiatum (Gardner) R.M. King \& H. Rob.; D. Agrianthus myrtoides Mattf.; E. Austroeupatorium inulifolium (Kunth) R.M. King \& H. Rob.; F. Ayapana amygdalina (Lam.) R.M. King \& H. Rob.; G. Ayapanopsis oblongifolia (Gardner) R.M. King \& H. Rob.; H. Bahianthus viscosus R.M. King \& H. Rob.; I. Barrosoa betonicaeformis (DC.) R.M. King \& H. Rob. 

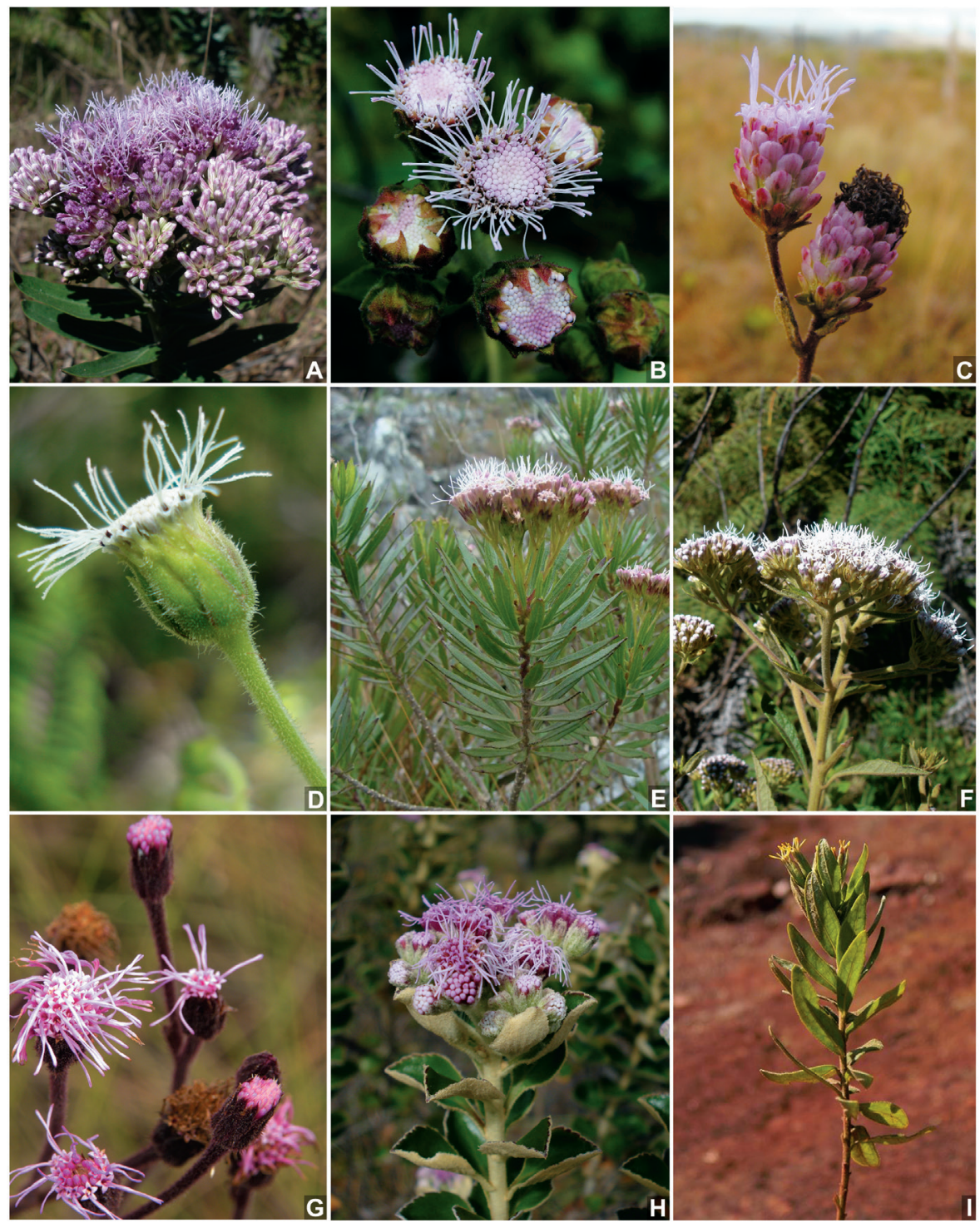

Figura 25. Eupatorieae. A. Campovassouria cruciata (Vell.) R.M. King \& H. Rob.; B. Campuloclinium megacephalum (Mart. ex Baker) R.M. King \& H. Rob.; C. Chromolaena horminoides DC.; D. Diacranthera ulei R.M. King \& H. Rob.; E. Disynaphia praeficta (B.L. Rob.) R.M. King \& H. Rob.; F. Grazielia intermedia (DC.) R.M. King \& H. Rob.; G. Heterocondylus pumilus (Gardner) R.M. King \& H. Rob.; H. Lasiolaena duartei R.M. King \& H. Rob.; I. Leptoclinium trichotomum (Gardner) Benth. 

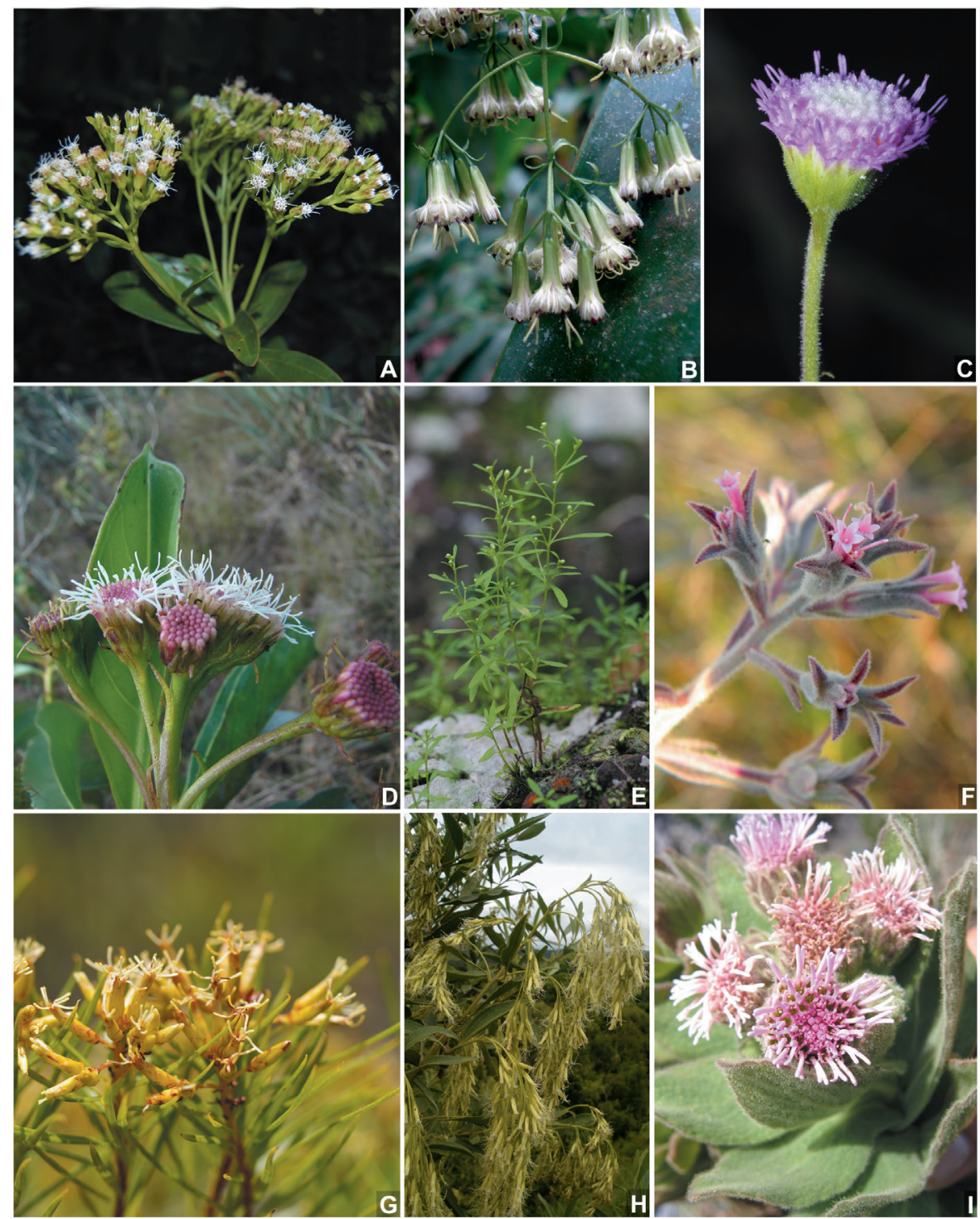

Figura 26. Eupatorieae. A. Litothamnus ellipticus R.M. King \& H. Rob.; B. Mikania ternata (Vell.) B.L. Rob.; C. Monogereion carajensis G.M. Barroso \& R.M. King; D. Morithamnus crassus R.M. King \& H. Rob.; E. Parapiqueria cavalcantei R.M. King \& H. Rob.; F. Planaltoa salviifolia Taub.; G. Pseudobrickellia brasiliensis (Spreng.) R.M. King \& H. Rob.; H. Raulinoreitzia crenulata (Spreng.) R.M. King \& H. Rob.; I. Semiria viscosa D.J.N. Hind. 

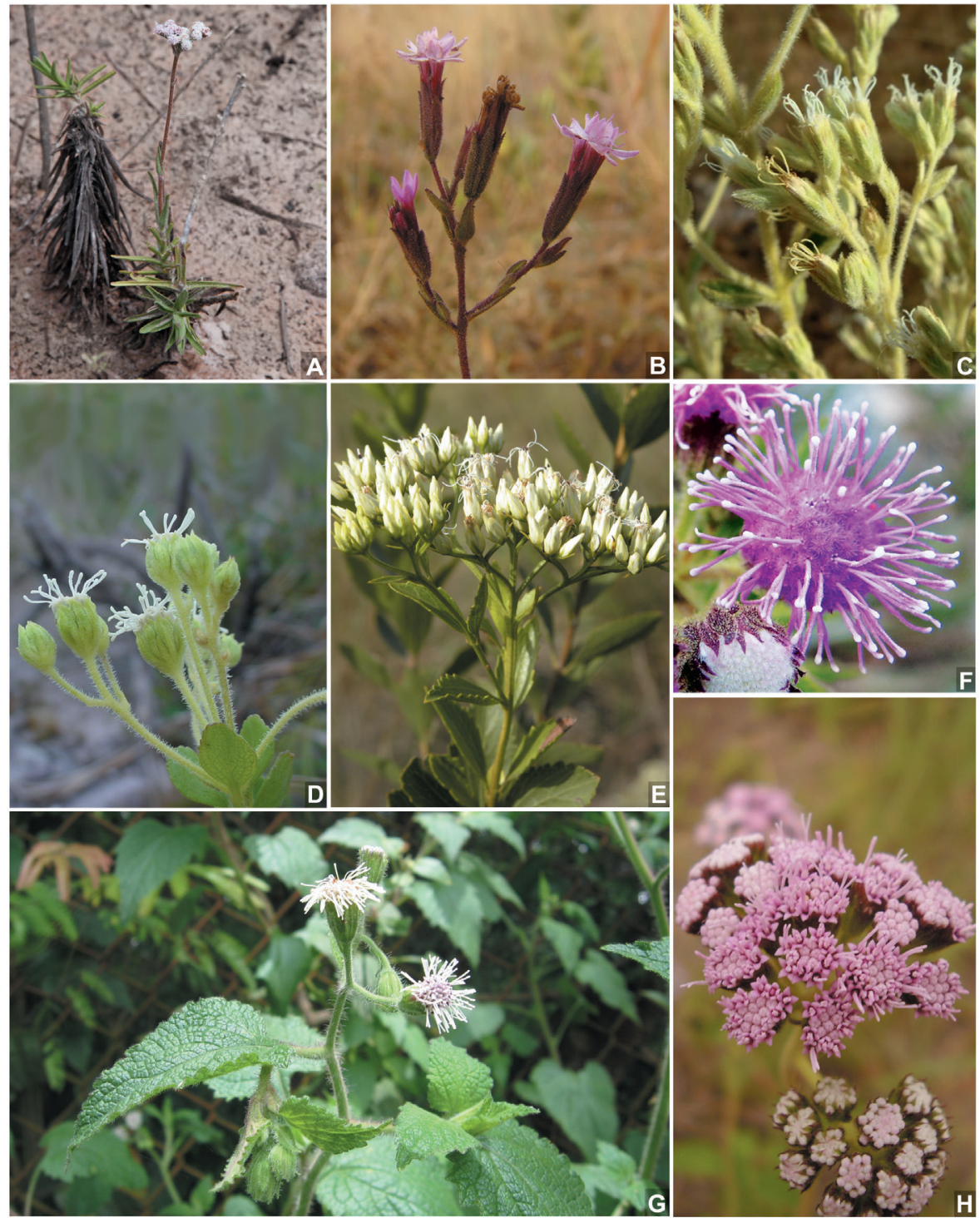

Figura 27. Eupatorieae. A. Scherya bahiensis R.M. King \& H. Rob.; B. Stevia heptachaeta DC.; C. Stomatanthes dictyophyllus (DC.) H. Rob.; D. Stylotrichium rotundifolium Mattf.; E. Symphyopappus cuneatus (DC.) Sch. Bip. ex Baker; F. Trichogonia villosa Sch. Bip. ex Baker; G. Trichogoniopsis adenantha (DC.) R.M. King \& H. Rob; H. Vittetia orbiculata (DC.) R.M. King \& H. Rob. 